\title{
RNF130 Gene
}

National Cancer Institute

\section{Source}

National Cancer Institute. RNF130 Gene. NCI Thesaurus. Code C111931.

This gene is involved in the ubiquitination of proteins. 